Sigrid Aksnes Stykket

Universitetet i Sørøst-Norge

\title{
Det blir ikke jul uten... Om tradisjoner rundt førjuls- og julehøytid
}

\author{
There is no Christmas without... \\ On Traditions around Christmas and the Time of Preparation
}

This article explores various Christmas traditions and how they have changed over time. Examples are taken from a rural area, Bø in Telemark, Southeast Norway. It focuses on the time of preparations, the celebration of Christmas Eve, and the festive season of the "romjul" from December 26 to Twelfth Night.

Key words: Christmas traditions, advent, Christmas dishes, Christmas tree, Christmas cards, Christmas gifts, Christmas festivity

Nøkkelord: Juletradisjoner, advent, julemat, juletre, julekort, julegaver, romjulsfester, julebukk

\section{Innledning}

Knapt noen tid på året har så mange faste tradisjoner som førjuls- og juletida i Norge. Og mange av dem er så faste at det kjennes som det ikke kan bli jul uten dem. Likevel skjer det stadig forandringer; det som måt te til for at det skulle bli jul for 30 år siden, er kanskje ikke det samme som må til i dag. Jeg skal her ta fram tradisjoner fra en liten del av Telemark, særlig Bø. Moltke Moe (1925) og Olav Nordbø (1960) skrev om det, og jeg sammenligner med det jeg selv husker fra ca. 50 år tilbake, og sier litt om hvordan tradisjonene praktiseres i dag. Det kan bli enkelte historiske tilbakeblikk over opphav og utvikling, og det kan bli sideblikk til andre steder i Norge, og eventuelt andre land, siden mange av disse tradisjonene er importerte. Noe kan jeg da belegge med kilder, men mye av det jeg skriver om, har jeg bare fra overført muntlig tradisjon. 
Det blir ikke en inngående gjennomgang av bakgrunnen for de ulike trådene som julefeiringa i dag er spunnet sammen av. Men de fleste er enige om at julefeiringa har en tredelt bakgrunn ${ }^{1}$ :

- en førkristen fest for de døde, selv om vi ikke har mange henvisninger til det i norrøne kilder. Men kanskje tilbedelse av de døde ligger bak både troen på Oskoreia og skikken med å sette ut julegrøt;

- en fest for å feire at "sola snur", og at vi går mot lysere tider igjen, det som Snorri Sturlusson i Olav den Helliges saga, kapittel 107-1092, kaller midtvintersblot. Blotet, det vil si offeret for å be om et godt kommende år, kan ligge bak for eksempel skikken med å sette opp julenek;

- en kristen feiring av Jesu fødsel, det som har vært den offisielle grunnen til å feire jul i de siste tusen år.

Det er få kilder fra førkristen tid, så her må man lage hypoteser og trekke slutninger ut fra det sparsomme materialet som finnes. De som virkelig har studert emnet, er klare på at lite kan slås fast sikkert. Men uansett kan vi vel være enige om at denne tida på året egner seg usedvanlig bra til litt festivitas og fellesskap som kan få tankene bort fra mørketid og kulde.

Jeg deler gjennomgangen inn i forberedelsestida, med et eget avsnitt om advent og om Lucia, eller lussidagen, så kommer en bolk om selve julaften, og så en avdeling om første juledag, romjula og avslutning av juletida. Den første delen blir adskillig mer omfattende enn de andre, siden forberedelsene favner vidt og mange sider må nevnes. Dersom man skulle gå inn i historisk bakgrunn og følge utviklingen av hver enkelt tradisjon, kunne det vært emne for en større avhandling. Her må jeg begrense meg til korte riss av enkelte av de tradisjonene som følger eller har fulgt julefeiringa.

\section{Forberedelser og førjulstid}

Å forberede jula har nok alltid tatt lang tid, og i det vi litt diffust kaller "gamle dager" var det mange detaljer å passe på. Å gjøre klar mat, hus og familie for julefeiring skulle skje etter mange uskrevne regler.

Fest er alltid forbundet med mat, og siden førkristen tid har jula vært ei tid for overdådig mat og drikke. Tidligere stod det i skarp motsetning til den daglige sparsomme kosten, mens forskjellene i dag ikke er så store. Før jul skulle man til

1 For mer om bakgrunn, se for eksempel Olav Bø (1974): Vår norske jul, Bakgrunn og eldste historie, s. 9-22 og Tr.Fr. Troels-Lund (1914-1915): Dagligt Liv i Norden i det sekstende Aarhundre/VII Bog. Aarlige Feste, s. 14-20.

2 Olav den Helliges saga ble opprinnelig skrevet som et enkeltstående verk omkring 1230. Senere inkorporerte Snorre det i Norges kongesagaer, som er det verket vi refererer til nå. 
og med holde igjen på maten for å bygge opp forventningene til det som skulle komme. Matforberedelsene omfattet blant annet slakting, eventuelt raking ${ }^{3}$ av fisk, ølbrygging og kakebakst. Når det var unnagjort, kunne man tenke på rengjøring av hus og fjøs, og til slutt kom den personlige hygienen. Vi skal se litt på hva dette kunne omfatte.

I dag er det ikke mange barn som har nærmere kjennskap til hvor juleribba kommer fra, men fra min barndom husker jeg faste bygdeslaktere som ble tilkalt for å ta seg av avlivinga av julegrisen. Det meste av slaktinga var unnagjort om høsten, og kjøttet var salta og tørka for å holde seg vinteren gjennom. Men julegrisen måtte leve til like før jul, den skulle gi ferskmat. Det var viktig å slakte på voksende måne, altså ved nymåne, og fløende sjø, ellers ble flesket udrøyt og kjøttet løst, ifølge folketroen. Slaktinga skjedde ved at grisen ble tatt med ut på tunet, ikke uten høylytte protester. Det er sikkert mange som fremdeles kan kalle fram i minnet de grisehyla som fulgte med denne tradisjonen. Kona på gården, eller slakteren, skulle si til grisen, enten $\mathrm{f} ø \mathrm{r}$ den ble stukket ${ }^{4}$, eller like etter: "Det er ikke for hat, men for mat!" Så snart slakteren hadde stukket grisen, var det kvinnenes arbeid å stå med et kar og fange opp blodet som rant. Griseblodet var en viktig ressurs for de fleste. Så var det slakterens jobb å skålde grisen og fjerne busta. En mann delte gjerne opp griseslaktet etter kvinnenes anvisning, og så var resten kvinnenes jobb. Flesk, ribbe, koteletter og steiker ble skåret opp og lettsaltet, og så skulle det lages blodpølse, blodpudding, kjøttkaker og medisterkaker, pølser, lungemos, sylteflesk og syltelabber, og smult ${ }^{5}$ til baksten. Sylteflesk er fortsatt del av den faste oppdekkinga på julefrokosten, og ribba den selvsagte hoveddelen av julemiddagen for de aller fleste ${ }^{6}$. Men maten blir innkjøpt på butikken, og få skjenker opphavet en tanke.

Brygging av øl har vært fast tradisjon helt siden vikingtida. Den eldste omtalen av jul i Norge finnes i et kvede som antas å være fra 900-tallet ${ }^{7}$, og da i forbindelse med å "drikke jul". Dette impliserer at det skulle utbringes skåler, eller drikkes til ære for noen, sannsynligvis for de gamle gudene Odin, Tor og Frøy. Gulatingslova, som ble nedskrevet fra slutten av 1100-tallet, har påbud om at minst tre bønder skulle gå sammen om å brygge øl til jul, så sant de ikke bodde så langt ute på øyer eller høyt til fjells at samarbeid var umulig. Loven sier også at ølet skal "signes for å takke Kristus og Santa Maria, for godt år og fred" (Gulatingslova I 6)

\footnotetext{
$3 \quad$ Å rake fisk: å salte og legge til oppbevaring for at den skal fermenteres.

4 Å stikke en gris: å avlive ved å skjære over halspulsåren, vanligvis etter at dyret først er bedøvet med et skudd gjennom hjernen ved hjelp av en såkalt slaktemaske.

$5 \quad$ Smult lages av det løse bukfettet på grisen, se Smult...

$6 \quad 76 \%$ på Østlandet, 55\% av hele landet spiser ribbe, ifølge Høberg 2016.

7 Torbjørn Hornkloves, Haraldskvede, strofe 6: "úti vill jóldrekka ef skall einnráða" (ute på havet vil han drikke jul, om han får bestemme alene).
} 
(overs. S.A.S.). Det er naturlig å regne påbudet som markering av et brudd med den gamle skikken med å signe det til gudene.

Mange steder har menn tatt opp igjen skikken med å brygge til jul etter gamle oppskrifter, gjerne flere menn sammen. Dersom man googler "brygge øl selv" eller lignende, får man veldig mange treff, og hvert år har lokalavisene artikler om menn som har tatt opp den gamle tradisjonen med å brygge, ofte ganske sterkt $\varnothing l^{8}$. Og plikten til å brygge, og antall menn som skal være sammen om ølbrygging, er altså slått fast allerede i Gulatingslova. Den gamle tradisjonen forutsatte at man hadde malt tilgjengelig (spiret og tørket korn, som regel av bygg), gjerne sammen med tørkede humleblomster. Ølet skulle være sterkt, og at inntaket forventes å være stort i jula, underbygger Troels-Lund med et par ordtak eller sitat: "«lkke at have Raad til en Rus i Julen» var Betegnelsen for den ynkeligste Armod" (Troels-Lund 1914-1915: 82) og " "Julespy var glemt før Faste»" (Troels-Lund 1914-1915: 83).

Mot slutten av 1800-tallet, da avholds- og måteholdsbevegelsen sto sterkt, kom det alkoholfrie ølet (Blehr Lånkan 2017). Det kom et fabrikkprodukt med tørket humle og malt som kunne tilsettes vannet sammen med gjær og sukker, og ølbrygging ble husmorarbeid, i alle fall på Østlandet. Etter 1-2 dagers gjæring var "kjerringølet" klart til å tappes på flasker. Ølet måtte ha 8-10 dager på flaske før det var klart til å drikke. I dag er det fortsatt en del som lager kjerringøl, kanskje særlig i distriktene, samtidig med at særlig menn har tatt opp den gamle ølbryggetradisjonen, som nevnt.

I tidligere tider hørte også brenning av julebrennevin til, fram til hjemmebrenning ble forbudt i 1840 -åra.

I store deler av det indre østlandsområdet var det vanlig å legge ned rakefisk til jul: ørret og røye, eventuelt andre feite ferskvannsorter, ble lagt i saltlake og fermentert. Rakefisken er dokumentert allerede på 1300-tallet. Og denne tradisjonen holdes fortsatt i hevd, særlig i Valdres, men også i Telemark, Hallingdal, Østerdalen og flere andre områder.

Ikke bare kjøttmaten skulle være spesielt god. Baking har også vært viktig. I eldre tid var det mulig å lage finere variasjoner av flatbrødet. Ved å bruke mer av dyre ingredienser som finmalt mel, smør og sukker i deigen, fikk man lefse eller kling, som så ble smurt med smør og sukker, og så var det festmat.

Bakstekjerring var et eget yrke, hun dro fra gård til gård for å stå for bakinga, men da var det flatbrødtyper som ble bakt. I tidligere tider ble småkaker innkjøpt, i alle fall nær de store byene. Det fantes profesjonelle yrkesbakere i Oslo, Bergen og Trondheim allerede fra 1300-talet, og vi har en omtale av en særskilt bakerstue ved Elgeseter kloster i Trondheim alt i 1240 (Bø 1970: 33). Fra 1800-tallet, da bakerovner etter hvert ble vanlig på gårdene, ble julekaker et eget begrep. Konven-

Se for eksempel $N y$ trend...

9 Navnet spiller på at dette var alkoholfritt øl, passende for "kjerringer" og unger. 
sjonen ble at man måtte ha sju slags kaker til jul, men hva de sju slaga omfatter, er det ingen enighet om. De eldste kaketypene er såkalte jernkaker, det vil si kaker som ble stekt i spesielle jernformer oppå ovnen, som krumkaker og goro. Deretter kommer smultbakst. I smult stekte man smultringer og fattigmann, rosettbakkels, krabbelurer, sprutbakkels, berlinerkuler og hjortetakk. De to første er nok de som var vanligst over hele landet, og særlig smultringer er fortsatt på de flestes bord i jula, enten de er hjemmebakt eller kjøpt fra butikk eller en av de tallrike smultring-buene som dukker opp før jul. Og så kom etter hvert alle de kakene man kunne steke inni bakerovnen, til jul var det først og fremst såkalte småkaker. Den kjente kokeboken til Hanna Winsnes fra 1845 har riktignok bare én oppskrift som spesifikt kalles julekake (en søt gjærdeig, som fortsatt heter det samme og hører med i tradisjonen), men enkelte andre oppskrifter der har trolig også vært brukt. I tillegg går jeg ut fra at våre formødre lenge har gjort det samme som jeg husker fra barndommen: husmødrene hadde håndskrevne oppskriftbøker og kopierte og delte oppskrifter med hverandre, men lot noen utvalgte oppskrifter bli værende innenfor familien. NRK Ni-timens lyttere hadde en stor avstemming for noen år siden, og da var det berlinerkranser, fattigmann, goro, krumkaker, sandkaker, sirupssnipper og smultringer som toppa lista. Andre "mest populær"-lister har bordstabel, hjortetakk, kakemenn, kokosmakroner, pepperkaker, peppernøtter, rosettbakkels og serinakaker på topp. Men selv om vi regner disse julekakene som noe typisk norsk, kan vi spore de aller fleste tilbake til andre land (Notaker 1993). Det er ellers mye mindre dokumentasjon om baking enn om brygging og slakting, som vanlig har kvinneaktiviteter ikke vært så interessante å skrive om.

Når de fleste matforberedelser var unnagjort, var det tid for storrengjøring: rengjøring av tak og vegger i tillegg til gulvet. Vi kan lese i norrøne sagaer om hvordan veggene ble pyntet til fest med store vevde tepper og smalere revler (av norrønt refill). Men det er faktisk bare i Bø, denne lille kommunen i Telemark, man fremdeles kan se rester av denne skikken når julehåndkloer blir hengt over gardiner eller andre steder til jul. Disse julehåndklærne er i hvit bomull, ganske smale, og avsluttet med et forseggjort heklemønster. Deres eneste funksjon er å være dekorative innslag til jul (se illustrasjon 1). Tidligere kunne de også bli brukt til å legge på kisten til en avdød, og fulgte da med i graven. De færreste vasker tak og vegger før jul i dag; men etter at elektrisiteten kom, blir det heller ikke så skittent av røyk og sot som i tidligere tider.

Av nyere førjulstradisjoner må nevnes julehefter, julekort og julebord. Mange vil si at det blir ikke jul uten noen av disse. Litterære julehefter dukket først opp tidlig på 1800-tallet, da kjente forfattere ofte fikk god betaling for å skrive der, og kunstvedlegg fulgte også ofte med. Det første som kom regelmessig, var Juleroser, egentlig et nordisk julehefte, som kom ut fra 1881 til 1936 (Brenne 2009). Senere kom også mange kristne organisasjoner med egne julehefter i store opplag, noen få eksempler 


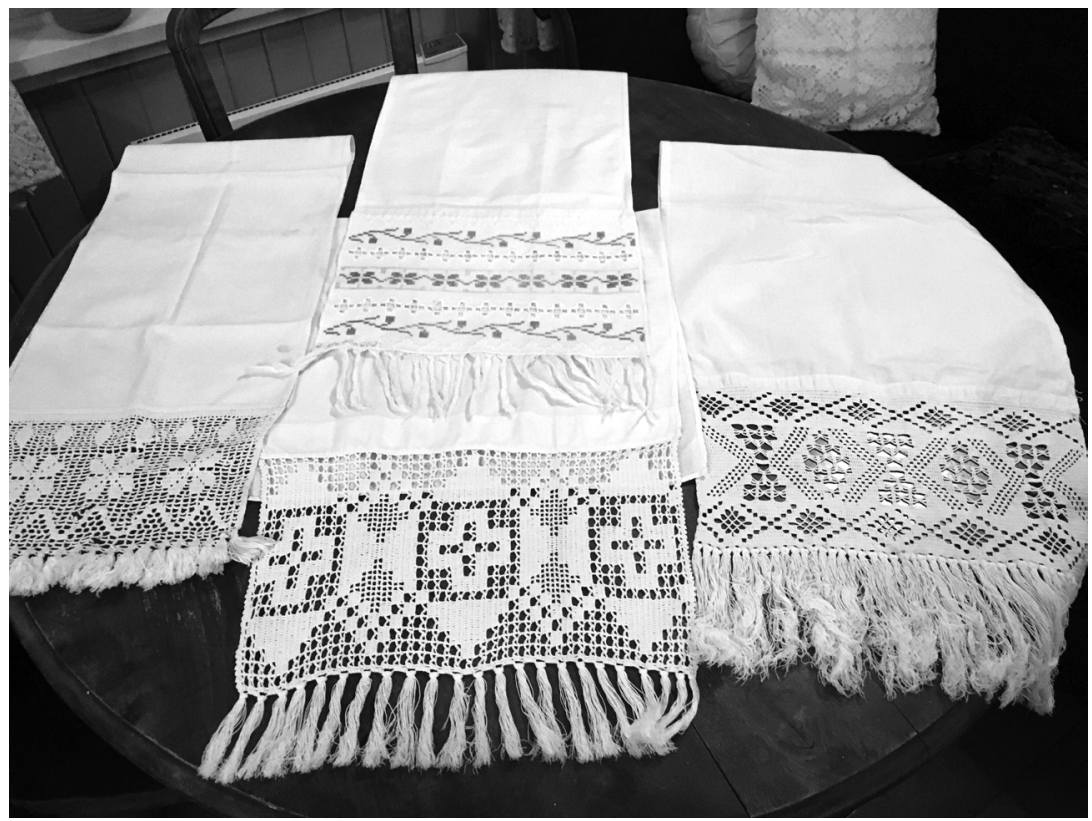

Illustrasjon 1. Gamle julehåndklær på utstilling, 2018

Kilde: egen samling (fot. Sigrid Aksnes Stykket).

kan være Fiskerens Venn (Den indre Sjømannsmisjon), Sambåndet (Det Vestlandske Indremisjonsforbund) Samenes Venn (Norges Samemisjon), Santalklokken (Santalmisjonen), Den store Glede (Pinsebevegelsen), Ved Juletid (Norsk Luthersk Misjonssamband) og Julefryd (Metodistkirken). Disse er nesten borte, men de siste årene har de litterære juleheftene fått en renessanse. Juleroser het et nytt julehefte i 2015 fra Samlaget, som tydelig ønsker å bygge på den eldste tradisjonen, med anerkjente forfattere og illustratører, og til og med under samme navn som det aller første årlige juleheftet. De lokale historielagenes julehefter ser også ut til å holde stand (Jul i Sogn, Jul i Sunnfjord, Jul i Hallingdal, Jul i Telemark, Hardangerjul og flere, som alle kommer på lokale forlag). Men langt de fleste juleheftene er tegneserier. Siden det første Knoll og Tott kom i 1911, har det blitt solgt millioner av oversatte internasjonale hefter, som Knoll og Tott, Blondie, Fiinbeck og Fia, Hårek, Pusur, Tommy og Tigern og utallige andre. Men vi har også fått noen rotnorske varianter, som Smørbukk, Vangsgutane, Tuss og Troll, Nils og Blåmann og 91. Stomperud (som riktignok først kom fra Sverige, men som etterhvert fikk et svært norsk uttrykk). På 2000-tallet har det kommet flere nye skudd på denne stammen, som Pondus og Nemi. Og dette er absolutt en levende tradisjon. I 2018 gav "julehefteforlaget" Egmont ut 35 ulike julehefter, av disse var 16 norske (se eksempler i illustrasjon 2$)^{10}$.

10 For en viss oversikt over hva som har vært i salg, se Serie Antikvariatets... 


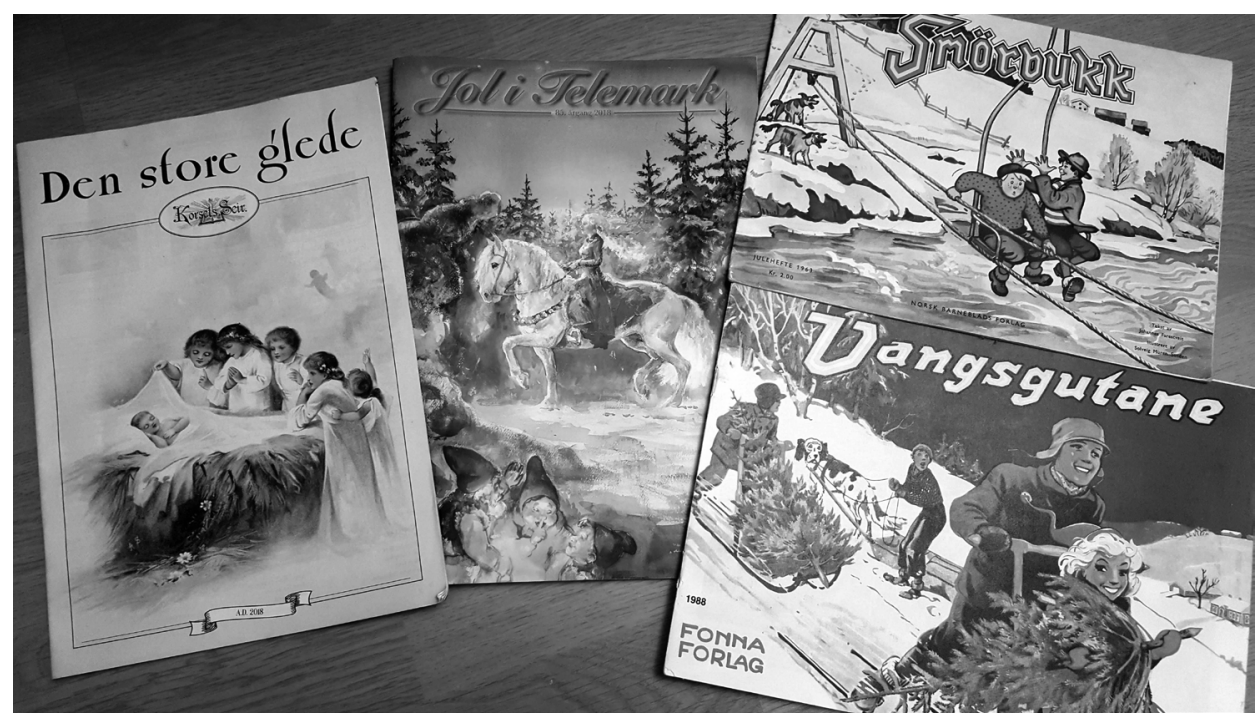

Illustrasjon 2. Julehefter for barn og voksne

Kilde: egen samling (fot. Sigrid Aksnes Stykket).

Julekortene derimot, med gode ønsker for julen til slekt og venner, har hatt en markert nedgang de siste årene, selv om man i 2017 fortsatt sendte mellom 10 og 13 millioner julekort i Norge. Denne skikken dukket først opp i England på 1840-tallet, og det første kjente norske julekortet er fra 1870-årene. I 1993 sendte hver nordmann i snitt opp mot 20 julekort, men siden har nok internett og sosiale medier tatt over mye av denne tradisjonen. Og dersom man fortsatt sender i posten, så er det ofte med personlige bilder av familie eller barn, ikke de masseproduserte. Men de fleste av oss kan nok fortsatt nikke gjenkjennende til motivene av f.eks. Trygve Davidsen eller svenske Jenny Nyström, to av de mest populære julekorttegnerne.

Julebordet var før i tida det oppdekkede bordet i julen, som i hvert fall den første julenatten skulle stå med brennende lys og mat på bordet. Da skulle de underjordiske, og eventuelt fattige som kom for å tigge, også kunne forsyne seg fritt. Den tradisjonen er borte, men navnet har blitt overtatt av det førjulsselskapet som svært mange bedrifter nå arrangerer for sine ansatte. På dagens julebord blir alle de tradisjonelle julerettene servert. Mange steder hører også mengder av alkohol med, slik at et google-søk på julebord gjerne kommer opp med forslag som "julebord og fyll", "gjør du dette på julebord, kan du få sparken", "julebordtabber" og lignende. Denne formen for julebord dukket først opp på 1960-tallet, og har kanskje begynt å gå litt tilbake de siste årene.

Adventstida er tid for det meste av juleforberedelsene, men advent var i utgangspunktet ei kirkelig forberedelsestid. Kirkeåret starter som bekjent på første 
søndag i advent med ei innvielsestid der man venter på Kristi komme. Den adventskransen vi bruker i dag, har bakgrunn i Tyskland i 1831, der en teolog ville anskueliggjøre ventetida ved å lage en ring av eviggrønne vekster, med et stort lys for hver søndag (Thomassen 2018). Etter hvert ble denne også tatt inn i hjemmene, sammen med adventsstjernen. Adventskalenderen eller julekalenderen er også en tysk videreutvikling av kransen, fra de fire lys for hver adventssøndag til en liten gave for hver dag i desember. Den første fra Tyskland dateres til 1902, den første i Norge 1947. Dette har blitt en tradisjon for de aller fleste norske barn. Innholdet i gavene var først bare et lite bilde innenfor en luke. Senere ble noen julekalendere laget med små sjokoladefigurer. I dag har det hos mange blitt til omhyggelig utvalgte gaver som nesten kan erstatte en julegave. Videre har vi så fått julekalenderprogram på TV, med en daglig episode fra 1. desember til julaften. Dette begynte på NRK på 1980-tallet, og mange av seriene har oppnådd usedvanlig høye seertall. De første julekalender-programmene gikk på Barne-TV, men senere har de også blitt laget som humorprogrammer for voksne.

\section{Lucia, lussi langnatt}

Luciatradisjonen er todelt, det er den mørke, farlige Lussi, som virker som den eldste i Norge, og så har den lyse Lucia kommet inn fra Sverige i noe senere tid. I tradisjonen heter det at Lussi var den første kona til Adam, og fra henne stammer alle de underjordiske. Sammen med henne var onde vetter og daudinger denne natta. Lussinatta, mellom 12. og 13. desember, var den lengste natta i året, i alle fall så lenge vi brukte den julianske kalenderen. Selv om man skifta til den gregorianske på 1700-talet, holdt man fast på at lussinatta fremdeles var den lengste og den farligste. Da måtte man gjøre seg tidlig ferdig i fjøset, og holde seg innendørs for å ikke bli tatt av lussireia/oskoreia, som kom farende gjennom lufta. Da var det godt å ha malt et tjærekors på alle dører og på stallen, så ikke man selv eller hesten risikerte å bli tatt med på det ville rittet. Man kunne kanskje også se ansiktet til Lussi på vinduet. Hun sjekka om man var godt i gang med juleforberedelsene. Dersom man ikke hadde fått gjort det nødvendigste, kunne hun rive ned toppen av pipa. Og katten hennes, en lussekatt, var selvsagt en trollkatt. Når vi baker lussekatter, så tilsettes safran, den gule fargen symboliserer lyset, som holder djevelen borte. Lussekatter ble i Sverige før kalt dyvelskatt eller döfvelskatt (djevelkatt) (Grosvold 2016). Også denne skikken kommer sannsynligvis fra Tyskland.

Denne natta kunne dyra snakke sammen, men om du prøvde å høre på dem, risikerte du å miste livet. Men noen hadde tydeligvis hørt på likevel, for mange steder refereres noe tilsvarende dette som Moltke Moe har skrevet opp fra $B \varnothing$ : "«Lussinatta lange», sa kua, og beit tre gonger i bandet sitt. «Ho e lang som to» sa 
bekaren. «Skåmm få hennar, hått ho e», sa geita. Ho tosse ho blei drug, ho!”11 (etter Liv Bratterud, Moe 1925: 117).

Den farlige Lussi er en nordisk skapning, men Luciadagen er til minne om Lucia fra Sicilia, som ble martyr på 300-talet. I Sverige feira de julestjerna og de tre vise menn (i stedet for på Helligtrekongersaften, som andre steder), så der ble det lysfeiring. Troels-Lund forteller om feiring av lysfest med flere hundre elever på "Trivialskolen" i Stockholm allerede i 1743 (Troels-Lund 1914-1915: 22).

\section{Julaften}

Mange av de forberedelsene som skulle gjøres, måtte vente til julaften. Mye av det som skjedde på denne dagen og senere i jula, kunne også tolkes som varsler for det kommende året.

Juleneket (spikkebandet), kornneket til fuglene, skulle settes opp på fastende hjerte, altså det første som ble gjort om morgenen, eller kl. 12. Det var svært viktig at det ble stående rett opp og ned; dersom det stod skjevt, så varslet det at noen var $f_{e i g}{ }^{12}$, at noen ville dø i det kommende året. Etterpå drakk de spikkebandsdrammen. Noen satte også murukvist ${ }^{13}$ på husmønet til jul, for å sikre seg at alle fikk sove uten at mara kom og holdt dem fast om natten, altså uten noe mareritt.

I fjøset skulle det gjøres ekstra godt rent på julaftens morgen, og dyra skulle ha litt ekstra høy, noen kostet på et kornband til hver ku, og hilsenen "Et godt og trives godt, i kveld er det julaften!" Noen steder satte de et beskyttende kors over hver ku. Det vanligste var nok å sette kors over hver dør, og kanskje over vindusgluggene, for å verge seg mot de onde kreftene som var ute på denne mørke tida.

Kl. 12 spiste man eftasgraut (rømmegrøt). Dersom det ikke ble flot (utkokt fett som flyter) på grøten, så ville det bli det et skralt år, dårlig med grøde. Et grøtfat ble også satt ut til haugebonden til langt ut på 1900-tallet. På gårdene jeg kjenner til, og sikkert andre steder, stod fatet under tuntreet, oftest en gammel eik ${ }^{14}$. Fra gammelt av måtte alle bade på julaften når alt nødvendig arbeid var ferdig. Vann ble båret inn og varmet opp i badstua eller i stamp inne, og man badet alltid etter

11 Normalisert: "Den er lang som to" sa saubukken. "Skam få den, som den er lang!" sa geita. Hun syntes den ble langdryg, hun.

12 Opprinnelig betydning av feig (norrønt feigr): "som snart skal dø", sekundært har det fått inn fra tysk den betydningen som er mest brukt i dag, "motsatt av djerv, tapper; lite modig", se Bokmålsordboka...

13 Murukvist, marekvist, heksekost: en gruppe kvister som har vokst sammen på grunn av soppangrep.

14 Så lenge tuntreet levde, ville det gå godt på gården. Opprinnelig var det et hellig tre som ble planta over grava til den som rydda og grunnla gården. Han ble kalt haugebonden, fordi han var hauglagt, det var kastet opp en haug over grava hans. 
tur: først husbonden, så kona, så tjenestefolka, og til slutt barna (Moe 1925: 118). Etter badet skulle den nybadede høytidelig håndhilse på alle i huset med et fast uttrykk, som i Bø lød "God kveld og takk for sist, gledelig jul og helse og helbred og lykke og velsignelse til alt det som godt er", og så fikk han en dram og litt øl og litt å bite i (Moe 1925: 118). I min barndom uten innlagt vann badet vi også, men rekkefølgen var nok den motsatte, og den tradisjonelle hilsenen var borte.

Kl. 17 måtte forberedelsene være ferdige. Da ble jula ringt inn fra alle kirker, og på gårdene som lå lenger borte, kunne man skyte jula inn. Mennene skjøt tre skudd opp i lufta for å markere at julefreden startet. Denne skikken har trolig røtter langt tilbake, da man skulle skremme tusser og underjordiske fra å komme til gårds. Senere ble det bare en markering av at nå er høytida inne. Denne skikken har vært $\mathrm{i}$ bruk fram til nåtida, og i dag tar man nye metoder i bruk for å minne om noe som bare var selvsagt før. Her er et innlegg fra 23. desember på en Facebook-side for det grendelaget jeg tilhører:

Om 25 timar er det jul igjen :)! Håper det er rektig mange som følger tradisjonen med å skyte inn jula med tre skot i lufta kl. 17.00. I Eikjabygda - og sydover mot Kleppe skal det vera mange som disponerar minimum cal. 6,5 $\mathrm{mm}$ og oppover... "me hørast!" Og God Jul :).

Fra helt gammelt av har julehelga vært fredhellig, ingen skal straffes eller drepes i helgedagene, verken folk eller dyr. Vikingene drakk "til árs ok friðar"- for godt år og fred (frið kunne også bety kjærlighet og fruktbarhet, det kan derfor også ha vært et frukbarhetsønske i det). Derfor går aldri noen på jakt i juletida. Og at dette også kan utvides til å gjelde i krig, har vi flere fortellinger om fra første verdenskrig. Særlig jula 1914 skjedde det i mange skyttergraver langs hele fronten, uten at noe var avtalt på forhånd, at tyskere, franskmenn og engelskmenn kom opp av skyttergravene og utvekslet gaver som sigaretter, sang julesanger, og til og med sparket fotball sammen. Freden varte til midnatt etter første juledag, og da den britiske generalstaben fikk høre om det, gav de strenge forbud mot all "fraternisering med fienden". Neste jul var det ikke så mange steder det skjedde, men det er likevel dokumentert noen steder. (Et søk på Julevåpenhvilen vil gi mange treff på Google, bl.a. fra National Geographic 22. desember 2014).

Skikken med å tenne lys på gravene til de som er borte, kom ikke til Norge før litt etter første verdenskrig. Katolikkene tente først lys på Alle Sjelers dag 2. november. Skikken spredte seg fra dem, og byttet tidspunkt, selv om ikke alle i vår protestantiske tradisjon var like positive til denne skikken i utgangspunktet. Men for mine barn og barnebarn vil nok besøket på kirkegården med lys og gravpynt være noe av det de vil huske som sin juletradisjon. Dette kombineres for mange med å gå til julegudstjeneste. Selv om kirkebesøket har gått drastisk ned ellers 
i året, er norske kirker overfylte på julaften, mange kirker må ha to gudstjenester for at alle skal få plass.

Når alle er hjemme igjen, er det julekveldsmiddag. Ribbe har som nevnt lang tradisjon på hele Østlandet, mens de fleste på Vestlandet har pinnekjøtt. I fjellbygdene i Telemark var det vanligere med fersk ørret eller røye sammen med fiskesuppe og kling. Men velstandsstigning og mindre fokus på sjølberging ${ }^{15}$ førte til at ribba fikk førsteplassen her også. Fra gammelt var det en selvfølge å be en bordbønn, og dersom man ikke hadde vært i kirken, leste gjerne far i huset juleevangeliet, og så skulle Juleverset synges. Det var første vers av salmen "Et lidet barn så lystelig", og har blitt sunget til ulike folketoner over hele Norge. Dette er en opprinnelig tysk salme, oversatt til dansk 1529, og senere med i Kingos danske salmebok. Denne var i bruk også i Norge til den ble avløst av den første norske, M.B. Landstads kirkesalmebok fra 1870 . Her er verset gjengitt i Grundtvigs oversettelse.

Et lidet Barn saa lystelig
Er født for os paa Jorden,
Af Moder-Mø saa yndelig,
Han er vor Frelser vorden!
Var ei den Søn af Jomfru reen,
Vi gik forloren, hver og Een,
Paa ham alt Haab vi grunde!
O søde Herre Jesus Christ!
Du, som er Gud og Mand forvist!
O fri os fra den Onde!

Da juletreet kom til Norge fra 1800-tallet, først hos prester og embetsstanden i byene, var det et poeng at barna ikke skulle få se det før det stod ferdigpyntet med godtekorger og levende lys. Man kan tenke seg at det må ha vært litt av en åpenbaring i tida før elektrisiteten kom! Nå er det ofte slik at nettopp barna skal være med og pynte, gjerne med selvlaget julepynt fra skole og barnehage. Og treet er ikke fullkomment før gavene er på plass under treet. Juletreet har også sitt opphav i Tyskland, fra reformasjonstida, da det var viktig å skape nye skikker som markerte jula som en familiefest knyttet til Jesusbarnet, og ikke til den katolske helgenen St. Nikolaus.

Gaveutdeling står det ingenting om i de gamle oppskriftene fra Bø. Men etter det jeg har hørt av de eldre, var det vanlig at alle i huset skulle få et nytt klesplagg til jul, om så ikke mer enn et par sokker. Gaveskikken er ellers gammel, men kanskje helst med å gi til sine arbeidere eller de fattige. I Norges kongesagaer leser vi at bl.a. Olav Haraldsson gav sine menn julegaver (Olav den Helliges saga kapittel 162).

15 Sjølberging: det å skaffe maten fra naturen uten å kjøpe den. 
Etter hvert skulle det være gaver til barna, slik Ludvig Holberg nevner i Julestuen fra $1724^{16}$. Med økende velstand har gavene blitt stadig dyrere. I lokalavisa Telemarksavisa 18. desember 2018 kunne bilselger Per Boseth Johansen fortelle at en mann hadde kjøpt en Jaguar I-pace First Edition til $900.000 \mathrm{kr}$ i julegave til sin kone, en annen skulle gi en diamantring til 200.000 kr. I mange land foregår gaveutdelingen på første juledag, i Norge har man også i dette fulgt tysk tradisjon og gitt gavene på julaften.

En gammel og utbredt skikk som ble borte for omkring 100 år siden, var å sit t e på julaften. Det hadde litt ulik utforming i ulike bygdelag. En vanlig variant var at den som var ugift og ønsket å få vite hvem man skulle bli gift med, skulle sitte oppe ved midnatt, når alle andre var gått til ro, med tre drikkeskåler foran seg, med øl, melk og vann i. Da ville han eller hun få se den tilkommende komme inn og drikke av den ene av skålene, avhengig av om de skulle bli velstående, ha det nødvendigste, eller bli fattige. Men den som satt, kunne også oppleve å få dødsvarsel dersom det var slik at han eler hun skulle dø i løpet av det kommende året. Dette finnes det mange oppskrifter av fra flere steder i Norge. Det er navngitt mange her i som $B \emptyset$ prøvde det, og fikk se den de skulle få, noe som selvsagt slo til (Nordbø 1960: 124-126).

Fra middelalderen av var det midnattsmesse i overgangen mellom julaften og juledagen som var tida for kirkegang. Etter reformasjonen ble det til en fromesse (tidlig messe) på førstedagsmorgen. Etter hvert ble det vanligere med en formiddagsgudstjeneste til vanlig kirketid kl. 11. Men i løpet av de siste par generasjoner har det blitt julaftens-gudstjenesten som har overtatt som den viktigste samlingen. På første juledag er det ikke lenger så strengt med julefreden som før. Tidligere skulle man ikke gjøre noe slags arbeid, og man kunne heller ikke gå på besøk denne dagen. Den skulle bare feires hjemme med alt det beste av mat og drikke.

\section{Romjulsaktiviteter}

Andre juledag var i kirkelig tradisjon Sankt Stefansdagen, minnedagen for kirkens første martyr Stefanus. Det eneste som var bevart av gamle skikker i Bø på denne dagen i starten av 1900-tallet, var at man denne dagen i all hemmelighet dro til naboens fjøs og stelte husdyra der. Denne skikken er naturlig nok falt bort, ettersom husdyrholdet forandret seg på andre halvdel av 1900-tallet. Før hadde alle som eide litt jord, minst ku og gris, kanskje også høns og noen sauer eller geiter, og eventuelt hest om det var fôrgrunnlag for det. I dag er det meste nedlagt, mens noen få gårder har spesialisert stordrift med bare ku, gris eller sau.

16 Jeronimus: "Det er Konst at deele Gaver ud blant Børn, saa alle kand blive fornøyet..." (Scene 11). 
Andre juledag startet julegilde-sesongen. Hele romjula ${ }^{17}$ var og er ei tid for festligheter, julestue, juletrefest eller juleselskap. Julestuen som selskapsform er belagt fra hele Norden fra 16- og 17-hundretallet, og i Norge har vi beskrivelser fra det meste av Norge (bl.a. fra Nord-Norge av Jonas Lie i Tremasteren Fremtiden og Nils Lagli i Julspel i Ranen). På den ene siden var det sterk motstand fra myndighetene mot disse festlighetene. Dette kan nok forklares med at feiringen kunne bli ganske løssluppen, og at noen benyttet anledningen til å begå ulovligheter under dekke av at det hørte med til feiringen (forbud i Christian Vs norske lov av 1687, flere forsøk på innskrenkinger i 1629, 1682, 1726 og flere, nytt forbud i 1735). På den andre siden beskrives bemerkelsesverdig mange ulike leker, først og fremst for voksne, hvorav de fleste er borte og glemt nå. Det var sangleker, gjetteleker, panteleker, "tvekamper", smedevers o m eller til kjente personer, og kanskje dans. Jeg nevner bare kulturhistorikeren Kristofer Visteds (1873-1949) sammenfatning i en artikkel som først ble trykt i Speiderens julenummer 1938 (Visted 2016: 88-96) og Nils Lagli oppramsing av juleleker han kjente til fra Rana ved forrige århundreskifte (Lagli 1994). Lovforbudene eller utviklingen førte til at julestuene døde ut, i dag har vi to ulike "avleggere" av dem, det er juletrefester og juleselskap, men ingen lovgiving trenges for å regulere disse sammenkomstene. Juletrefestene oppsto på 1800-tallet, og forklaringen ligger i navnet. Etter at juletreet var innført, arrangerte prester eller skolelærere barnevennlige fester der man gikk rundt juletreet, sang julesanger, kanskje brukte noen av lekene fra tidligere tiders julestue og spiste medbrakte julekaker til kaffe og saft. Snart ble besøk av julenissen et fast, populært innslag. Han hadde gjerne med en liten gave til alle barn. På 1900-tallet ble disse offentlige festene arrangert av skolekretser, misjonslag eller andre organisasjoner i alle deler av landet. I dag klarer de ikke lenger å konkurrere med alle andre underholdningstilbud, men de finnes fortsatt. En typisk juletrefest av i dag kunne vi lese om i Vest-Telemark blad 4. januar 2019, der det gammeldagse understrekes i overskriften Jolefest på gamlemåten (Haugsgjerd 2019). De private juleselskapene har blitt tilpasset dagens omgangsformer. De er for familie eller en adskillig mindre vennekrets enn tidligere generasjoners bedarlag ${ }^{18}$. Mat og drikke er det viktigste, og underholdningen strekker seg kanskje til et spill eller en quiz sammen.

I min barndom var det "å gå julebukk" noe vi gledet oss til i jula. Det måtte skje mellom andre juledag og trettendagen. Jo flere som var sammen i følget, jo bedre. Vi kledde oss ut og laget julemasker der vi klippet hull til øyne og munn. Så var vi klare til å besøke naboene, snakke med fordreid stemme, og se hvor lenge man klarte det før man ble gjenkjent og måtte ta av masken. Belønningen var servering av julekaker og kjerringøl. Men det vi gjorde på 1950-tallet, var en avbleket

17 Tradisjonelt var det 26. desember til trettendagen 6. januar, nå regnes den vanligvis fram til nyttårsaften.

18 Bedarlag: den delen av ei grend som skulle bes i selskap, bryllup eller begravelser. 
versjon av den opprinnelige julebukktradisjonen. Fra 1700- og 1800-tallet har vi mange beskrivelser av julebukkferder, når et stort følge med utkledt ungdom (og delvis eldre) sammen med en ordentlig "julebukk" dro fra gård til gård. Julebukken kunne ha en kropp som var dannet av en stang med et stort klede over, eller være et forkledd menneske, men hodet var det mest skremmende. Det kunne være trukket med skinnet av en geitebukk med hornene bevart på, noen steder med kjeft som kunne åpnes og var rødmalt innvendig, og med stål og flint i halsen slik at det gnistret når den åpnet munnen (Bø 1974: 139-148; Hodne 1996: 128-132). Følget sang, danset, skremte ungene, og fikk så gaver eller mat til avslutning etter at de hadde kastet maskene og avslørt hvem de var. Noen mener opphavet kan være middelalderske, katolske mysteriespill og den djevlelignende figuren som kunne være med der (Bø 1974: 146-148). Andre mener å gjenkjenne guden Tors bukker i den gamle julebukken, og knytter det til førkristen fruktbarhetskult (Hodne 1996: 132). Ut fra kildene er det vanskelig å fastslå noe sikkert opphav. Julebukker kan vi kanskje ennå oppleve, men nå har det meste av utkledningsleken flyttet over til Halloween og blitt amerikanisert, så barna kler seg i innkjøpte skrekk-kostymer og varsler "trick or treat" ved døra, i stedet for å legge opp til en uanmeldt visitt.

Vi har sett at de gjennomgåtte skikkene fra juleforberedelser, julaften og romjul har ulik alder og ulikt opphav, førkristent, katolsk eller protestantisk, de kan være importert eller ha norrønt opphav, og være døende eller helt borte. Nye tider fører til nye skikker, og hvordan julefeiringen vil se ut om nye femti år, er det vel ingen av oss som kan spå om, men nettopp derfor er det viktig å ha dokumentert noe av det gamle.

Litteratur

Alsvik, H., Asker, R., Fetveit, L. (1971). Buskerud og Telemark i manns minne, Daglegliv ved hundreårsskiftet. Frå Nasjonalforeningens landskonkurranse for eldre. Oslo: Samlaget.

Bakken, H.S. (1952). Holbergs julestue. Bergens Tidende 19. Universitetsbiblioteket i Bergens spesialsamlinger, https://spesial.w.uib.no/?page_id=1086 [lest: 6.01.2019].

Berg, K.A., Tessem, L.B., Wiedswang, K. (1993). Julen i norsk og utenlandsk tradisjon. Oslo: Gyldendal, https://www.nb.no/items/URN:NBN:no-nb_digibok_2007112201023 [lest: 6.01.2019].

Blehr Lånkan, A.K. (2017). Før kunne du få bot hvis du ikke brygget juleøl. 25.12, https:// www.oblad.no/ol/olbrygging/historier/for-kunne-du-fa-bot-hvis-du-ikke-bryggetjuleol/f/5-68-354543 [lest: 4.09.2019].

Bø, O. (1970). Vår norske jul. Oslo: Samlaget, https://www.nb.no/items/URN:NBN:no-nb_digibok_2011052308122 [lest: 6.01.2019].

Bokmålsordboka, https://ordbok.uib.no/perl/ordbok.cgi?OPP=+feig\&ant_bokmaal=5\&ant_nynorsk $=5 \&$ bokmaal $=+\&$ ordbok=begge [lest: 4.09.2019].

Brenne, T. (2009). Norske julehefter. De littercere juleheftene fra 1880 til i dag. Oslo: Messel. 
Det er 100 år siden julevåpenhvilen. (2014). National Geographic. 22.12., http://natgeobloggen. no/2014/12/22/det-er-100-ar-siden-julevapenhvilen-i-stedet-for-a-drepe-hverandre-medkuler-og-gass-delte-soldatene-gaver-og-spilte-fotball/ [lest: 8.01.2019].

Eithun, T., Rindal, M., Ulset, T. (ed.). (1994). Den eldre Gulatingslova. Oslo: Riksarkivet, https:// www.nb.no/items/fa602c833912b90e8aa641 dca79de225?page=35\&searchText=gulatingslova [lest: 6.1.2019].

Grosvold, R. (2016). ABC nyheter: Lussekattenes djevelske opphav. 12.12., https://www.abcnyheter.no/livet/mat-og-drikke/2016/12/12/195263101/lussekattenes-djevelske-opphav [lest: 8.01.2019].

Grundtvig, N.F.S. (2019). Etlidet Barn så lystelig. 6.01., https://kalliope.org/en/text/grundtvig20010107165 [lest: 6.01.2019].

Haugsgjerd, O.Å. (2019). Joletrefest på gamlemåten. Vest-Telemark blad, http://www.vtb.no/nyhende/joletrefest-pa-gamlematen-1.2557154 [lest: 6.01.2019].

Høberg, E.N. (2016). Norsk Julemat. I: Store norske leksikon. 6.06., https://snl.no/norsk_julemat [lest: 6.01.2019].

Hodne, Ø. (1996). Jul i Norge, Gamle og nye tradisjoner. Oslo: Cappelen, https://www.nb.no/ items/URN:NBN:no-nb_digibok_2008080100063 [lest: 6.01.2019].

Holberg, L. (1969). Jule-Stue. I: F.J. Billeskov Jansen. Ludvig Holberg Vorker i tolv bind. Digteren. Historikeren. Juristen. Vismanden. Bd. 4. København: Rosenkilde og Bagger.

Hornkloves, T. Haraldskvœði (Hrafnsmál) (B1), http://www.heimskringla.no/wiki/Haraldskv \%C3\%A6\%C3\%B0i_(Hrafnsm\%C3\%A11)_(B1) [lest: 4.09.2019].

Johansen, P.B. (2018). En heldig kvinne får en Jaguar i julegave: - Jeg må ut og få kjøpt en veldig stor sløyfe. 18.12., https://www.ta.no/nyheter/okonomi-og-naringsliv/jul/en-heldig-kvinne-far-en-jaguar-i-julegave-jeg-ma-ut-og-fa-kjopt-en-veldig-stor-sloyfe/s/5-50-666765 [lest: 8.01.2019].

Lie, J. (1872). Tremasteren "Fremtiden", eller Liv nordpaa. København: Gyldendal, https://www. nb.no/items/3cfde334aa552ee8c0fd5bc983b2b88b?page=0\&searchText $=$ [lest: 6.01.2019].

Lagli, N. (1994). Julspel i Ranen. Norsk Folkeminnelags skrifter 139. Oslo: Aschehoug.

Moe, M. (1925). Folkeminne frå Bøherad. Norsk Folkeminnelags skrifter 9. Oslo: Norsk Folkeminnelag, https://www.nb.no/items/URN:NBN:no-nb_digibok_2015012008071 [lest: 6.01.2019].

Notaker, H. (1993). Ganens makt. Norsk kokekunst og matkultur gjennom tusen år. Oslo: Aschehoug, https://www.nb.no/items/0f903bfaef4eb8f9680d2d60e2584607?page=0\&searchText=Ganens\%20makt [lest: 6.01.2019].

Nordbø, O. (1960). Før i tida. Gamalt or Bøherad. Norsk Folkeminnelags skrifter 85. Oslo: Universitetsforlaget, https://www.nb.no/items/URN:NBN:no-nb_digibok_2007041101105 [lest: 6.01.2019].

Ny trend: De brygger sitt eget $ø l . ~(2014)$, https://www.godt.no/artikkel/23274364/ny-trend-debrygger-sitt-eget-oel [lest: 4.09.2019].

Serieantikvariatets samling av julehefter, https://www.serieantikvariatet.no/products/Julehefter/257 [lest: 4.09.2019].

Sturluson, S. (1995). Norges Kongesagaer. Bd. 1-2. Oslo: LibriArte, https://urn.nb.no/URN:NBN:no-nb_digibok_2009120104101 [lest: 6.01.2019].

Thomassen, M. (2018). Advent. I: Store norske leksikon. 20.02., https://snl.no/advent [lest: 8.01.2019].

Troels-Lund, T.F. (1914-1915). Dagligt Liv i Norden i det sekstende Aarhundre/VII Bog. Aarlige Feste. København: Gyldendal, http://runeberg.org/dagligt/7/0012.html [lest: 6.01.2019]. 
Uggerud, E. (2016). Smult. I: Store norske leksikon. 25.05., https://snl.no/smult [lest: 17.04.2019]. Visted, K. (2016). Jul i gamle dager. Tekster av Kristofer Visted. Norsk Folkeminnelags skrifter 171. Oslo: Spartacus, Scandinavian Academic Press.

Winsnes, H. (1845). Lorebog i de forskjellige Grene af Huusholdningen. Christiania, https://www. dokpro.uio.no/litteratur/winsnes/frames.htm [lest: 6.01.2019].

Torbjørn Hornklove. (1912). Haraldskvæði ("Hrafnsmál"). I: F. Jónsson (ed.). Den norsk-islandske skaldedigtning. København: Gyldendal, http://www.heimskringla.no/wiki/Haraldskv\%C3\%A6\%C3\%B0i_(Hrafnsm\%C3\%A11)_(B1) [lest: 6.01.2019]. 